\title{
KIDLAT TAHIMIK AND THE DETERMINATION OF A NATIVE FILMMAKER
}

\author{
Patrick F. Campos \\ University of the Philippines Film Institute \\ patrick.campos@gmail.com
}

\begin{abstract}
Using field notes drawn from participative research in the context of his home life in Hapao, Ifugao and Baguio City, Benguet, as well as information gathered through interviews with his family, confidantes, and mentees, the article revaluates the oeuvre of pioneering independent filmmaker, Kidlat Tahimik. It is written self-reflexively, approximating the critic's process of understanding Kidlat's work through the lenses of a personal encounter. It critiques Kidlat's cinema, with special focus on Why is Yellow the Middle of the Rainbow? (1994), and reads it as his determination to author himself as "native" and "Third World" filmmaker, the same determination that animates the "independence" of his film practice.
\end{abstract}

\section{Keywords}

Independent Cinema, Kidlat Tahimik, Philippine Cinema, Third Cinema

\begin{abstract}
About the Author
Patrick F. Campos is Assistant Professor at the University of the Philippines (UP) Film Institute. He is currently Director of the Office of Research and Publication of the UP College of Mass Communication, University of the Philippines, Diliman, where he previously served as College Secretary. He is co-author of Communication and Media Theories (UP Press, 2014).
\end{abstract}




\section{KIDLAT, AUTEUR}

I catch sight of Kidlat Tahimik on our first morning in Hapao, Ifugao. ${ }^{1} \mathrm{He}$ is filming a ritual of the burning of the bones of more than a thousand nameless Japanese soldiers, near the site where, at the close of World War II, Gen. Tomoyuki Yamashita had surrendered to the returning Americans. ${ }^{2}$ Kidlat is garbed in a wellworn hand-painted shirt and a bahag (loincloth). A beaded necklace and a mini-DV camera are hanging round his neck, tangled with his long grey beard and hair. He is pointing his lens, now here on a puppy strolling among charred bones, now there on people gathering ashes in boxes, now over the shoulder of an Ifugao scrutinizing rusty war explosives lined up on a makeshift bench like a bunch of bananas, and now stealthily toward a Japanese man he is chatting with. There is no mainstream media to cover the ritual, held high up in the mountains of Northern Luzon, but Kidlat deems it a momentous event.

I and some filmmakers are here to make a documentary on Kidlat, to find out what constitutes his "independence" as an artist. Peering through my viewfinder, I eavesdrop as he tells a Japanese man about his upcoming installation. "I'm flying... Ifugao hut from...Philippine tanada (rice terraces or páy-yo) to...Japanese tanada as a 'love letter," he is saying. The moment allows me to see Kidlat as if I were watching all of his films all at once. For while auteurism may have already reached a critical impasse, ${ }^{3}$ the vagaries of the notion of the auteur are still personified by Kidlat Tahimik, not just in the sense of his being le realisateur (Kidlat Tahimik, "Midlife Choices" 14), but in the way that his personality has become apparently inseparable from his screen personage.

For instance, he has just met this man today in Hapao, and yet have I not seen this scene before, from Some More Rice (2005) - where the clanging of gongs meshes with his measured English, as he talks to a Japanese man by a hut on a rice terrace? Except that the scene was filmed years ago, and he was not in Ifugao then but in Japan, talking to a certain Mr. Takahashi, sharing the grief of the old man for the passing of the traditional tanada system of farming. In this film, Kidlat remembers how Akira Kurosawa's The Seven Samurai (1954) lionized not only the samurais of the sixteenth century (who, in the film, were jobless and needing "somemore-rice"), but also the imperiled farmers of Japan - with the samurais and the farmers signifying ways of life that have given way to modernization. The sight of placid bombs in the bone-burning ritual I am witnessing also calls to mind Kidlat's Our Bomb Mission to Hiroshima (1995), his filmic commentary on war history. The title invokes the memory of the bombing of Hiroshima by Americans; the film itself, however, is about an unexploded bomb that the Americans dropped in the Philippines in their war against the Japanese, found in a river in Baguio, transformed into a bell by Ifugaos, and brought back to Japan as a gesture of reconciliation. ${ }^{4}$ 
Kidlat's thoughts circle around his "love letter." The idea of sending an Ifugao hut to a Japanese tanada, he tells us, was at first merely a way of highlighting the wealth of wisdom shared by two ancient Asian cultures. But, like the eurekas that happen purposefully late in his creative process, after his conversations with the mumbaki (native priest) who is presiding over the bone-burning ritual, Kidlat realizes that he was, after all, set to make a gesture of peace yet again, in response to a historical juncture characterized by much conflict. This installation, then, this "lover letter," is like a sequel to Bahag Ko, Mahal Ko (Japanese Summers of a Filipino Fundoshi, 1996). In this film, Kidlat mourns the passing of the practice of wearing loincloth, though not only the Filipino's bahag but also the Japanese's fundoshi, implying how the process of shedding tradition tends to separate kinships of culture. The film vivifies Kidlat's disposition in a scene where he and a Japanese priest are shown wearing bahag/fundoshi, embracing on a bamboo bridge.

"Who else would send back these bones with dignity and in love?" Kidlat asks thoughtfully, during the feast of rice and roasted meat that followed the boneburning ritual. The mood of the environment is peculiar, because it is festive, with dancing and clanging of gongs. At the same time, it is solemn, as the Filipinos and Japanese move around the hearth, silently smiling at each other. Kidlat continues, "Filipinos are a peace-loving people. We are a bridge between East and West and a unique Asian race. If we would only stop denying who we are in hopes of being second-class Americans and do away with our American Idol orientation, we will be the race of the future." He pauses to think, and then jokingly and knowingly adds, "That's a racist statement!"

Speaking about peace, against hatred, of bridges that could span cultures and races - I have heard him talk about all of these in his films, even before I met him. For many years, in spite of being a world cinema figure, he has kept to the sidelines documenting events nobody else would film, like this ritual. Filming itself, for Kidlat Tahimik, is a ritual, a constant revalidation of reasons for (not) doing things, an incessant rehearsal of acted out statements made first of all for himself, and an obsessive re-playing of ideas that are supposed to run counter to (neo)colonial commonsense.

We see this in a memorable scene from Bakit Dilaw ang Gitna ng Bahaghari? (Why is Yellow the Middle of the Rainbow?, 1994), where his family insists on eating "the devil's meat" at McDonald's. Before they could enter the fast food restaurant, his children are required to chant, "Ronnie's burger..., money goes to Ronald Reagan," while Kidlat stays in the family van, cutting his hair in consternation, humorously committing "hara-kiri" and atoning for the sins of his family. The scene then cuts to an image of a cheeseburger, strewn with hair, being eaten by white mice; a few scenes later, a newspaper with the headline, "Fighting the Dictator in the US," and, 
over it, the voice of Kidlat talking to his son, saying, "You're right, it is harder to fight the dictator in us than to fight dictators in the US." More than a decade later, in the film, Dalawang Atang at Isang Pasalubong (Our Film-Grimage to Guimaras, 2006), Kidlat journeys to Guimaras, after an oil spill and, in solidarity with the townsfolk who are tying together rice stalks to break the waste-flow, he cuts the waist-length hair he has grown for ten years. He gives his hair as an offering (atang) and makes it part of the stopgap sponge. It is, in this sense, that Kidlat is an auteur, for his cinematic motifs and themes are variations of performative rituals of self(re)invention.

This is because, for Kidlat Tahimik, ritual is nothing if not repetition and fixation. This is exemplified in Bubong! (Roofs of the World! UNITE!, 2006), where Kidlat expresses surprise upon discovering how much roof-making footage he has accumulated through the decades, from shooting his first film in the 1970s in Europe, his travels with his sons in the 1980 os and 1990s, and the life-changing circumstances he has had to face in the Philippines in the 2ooos, such as when the house that his father had constructed in Baguio burnt down and when he had decided to build his own hut in Hapao. He turns these images of people at work on roofs into a collage, juxtaposed with images of ants, crumbs, candles, mist, dust, and ashes. Here we see the bases of his filmic rituals - a careful attention to and collection of the detritus of everyday moments and an urgeto remark on unremarkable details plotted and then encapsulated in spatiotemporal multiplicities. Each of his works is an evocation of particularities of places recorded at various times, unified in the present, first, by the retrospective consciousness of the filmmaker and, second, by the spectator who, according to critic E. San Juan, Jr., is positioned to be "chiefly skeptical, inquisitive, and partisan" ("Cinema of the 'Naïve" 276). Kidlat probes cinematic form, through associative juxtapositions, nondiegetic inserts, asynchronous sound design, percussive musical score, and voiceover, attempting always to arrive at a present but ongoing time.

Indeed, Kidlat's filmmaking is not separate from his waking and sleeping. At two in the morning, for example, roused by the rustling of his friend Lopes $\mathrm{Na}$ uyac, I awaken to see how Kidlat instinctively picks up his camera and shoots his friend unaware for a few seconds, before dozing off again. At five, before getting up, I spy as he shoots the stars still out and the bronze skies magnificently framed by the window of the hut, where we have been welcomed as honored guests. On a road trip, drowsy at dusk between Baguio and Ifugao, he asks his seatmate to pull down the window, so he can capture a shaft of light in the center of storm clouds beaming from the cracked heavens. How Kidlat works and how he talks about his work process are characterized by elfin but serious playfulness. He calls his method kapa-kapa [groping] filmmaking and his stories Bathala na [literally, "God's will be done"] scripts, which try to counter the colonially stigmatized notion of "bahala 
$n a$ " (i.e., come what may) fatalism. ${ }^{6}$ His artistic decisions seem whimsical, "but that doesn't mean I don't have any structure," he clarifies. "My structure is just broader. May daloy [there's a flow], but it allows for detours. It includes the whole cosmos. And I can take my time, because profit is not my motivation."

Kidlat is an avant-garde sophisticate, owing to the time and place when and where he discovered cinema, ${ }^{7}$ though his style, according to his once mentor, German director, Werner Herzog, is "primitive" (Kidlat, "Midlife Choices" 54-55; cf. de Guia, 105-106). "Primitive" is a double-edged term for it speaks a different meaning depending on the subject-position of the one who is listening (cf. R. Tolentino, "Jameson and Kidlat"). In any case, the term is controversial when associated with Kidlat, for it is, as such, helplessly associated with the term "Filipino."

That the Filipino, Kidlat Tahimik, rebelling against his Americanized upbringing, began filmmaking in the 1970 in Europe, rather than in the Philippines, inescapably situates his work in the cracks between auteur cinema and Third Cinema (cf. Staiger and Gerstner; Hillier; Martin; Crofts). The international modernism of the 1960s, which was the backdrop of Kidlat's discovery of cinema, fueled the engagement of the counterintuitive style of Western art and the revitalization of national cultural traditions beyond the west. The role of the author - or what authorship signified in art production was crucial in this engagement. The idea that the artist struggled to maintain his autonomy and originality against the homogenizing tendencies of bourgeois society and industrialism has prevailed in the west since the period of Romanticism. The same idea proved useful for European and Asian cinemas in the 1950 and 1960 s, when the French notion of auteur found directors who would live up to the role and when these same directors gained relatively small but devoted international followers. The romantic figure of the auteur, recognizable for a signature style and a palpable personality, stood against the dictates of commercial filmmaking and gave form to a "national" cinema, distinguishable from other national cinemas and Hollywood. Hence, Jean-Luc Godard was a French original, Ingmar Bergman Swedish, Michelangelo Antonioni Italian, Andrei Tarkovsky Russian, Satyajit Ray Indian, and Akira Kurosawa Japanese. It is in this spirit that Bienvenido Lumbera locates Kidlat as a Filipino artist, occupying a cultural niche in world cinema and standing in contrast to Hollywood and commercial filmmaking. ${ }^{8}$ Kidlat's undeniable style and personality easily secure for him the title of auteur.

But at the height of auteur cinema, Michel Foucault, in the influential essay "What Is an Author?" (1967), overturns the Romantic notion of the author that has come to "play the role of the regulator of the fictive, a role quite characteristic of our era of industrial and bourgeois society, of individualism and private property" (119). As I try to demonstrate below, it is precisely this role that Kidlat, by turns, avows and repudiates in constant tension, as borne by his films, and it is the 
same role that critics and observers ascribe to him with finality. For this reason, Kidlat's being an auteur is his boon and his bane. Lumbera's location of Kidlat is the shorthand explanation of Kidlat's independence, especially legible in today's terms of mainstream-versus-independent cinema. What the shorthand occludes, which I find necessary to emphasize, is not only the "complex operation" that has come to define Kidlat as a "Filipino auteur," or "primitive avant-garde," based on discourses (nationalist, auteurist) that animate his work, but, more important, the personal stakes and the price that he has had to pay to become a signifier of "Filipino independence."

If one begins with the assumption that Kidlat is an independent Filipino artist, then the markers of his aesthetics - the bahag, the clanging gongs, the melodious nose-flute, the rural landscapes - would appear to signify his independence and Filipinoness. But these signifiers only become apparent through the prior givens of a nationalist-auteurist discourse, assigning to the name Kidlat Tahimik a "classificatory function" (Foucault 107). As Foucault asserts, "[t]he author function is...characteristic of the mode of existence, circulation, and functioning of certain discourses" (108), and " $t \mathrm{t}]$ he author is also the principle of a certain unity of writing, (with) all differences having to be resolved" (111). That is, the very bases of "the interplay of those representations that formed a particular image" of, in this case, Kidlat Tahimik as independent and Filipino (bahag, etc.) have been his burden and have served to neutralize his discursive meaning (Foucault 105).

It is particularly germane to my brief discussion of Foucault's notion of the author function that "Kidlat Tahimik," which literally means "Quiet Lightning," is not the birth name of the auteur I am writing about. It is easy to see how the peculiar name readily lends itself to a nationalist reading and, with Eric de Guia's wilful adoption of the legal and fictive name whose connotation is situated between designation and description, we can see how the auteur chooses to inhabit a discursive construct and allows this construct/name to be his mode of being. That his name is picturesque and is associated with quite peculiar work serves to vivify Foucault's assertion that "the author's name...seems always to be present, marking off the edges of the text, revealing, or at least characterizing, its mode of being" (107).

While the meaning of the author's name/text is not entirely derived from the real individual's own being but is also always discursively constructed, "all discourses endowed with the author function do possess the plurality of self" and "give rise simultaneously...to several subjects - positions that can be occupied by different classes of individuals"(Foucault 112-113). "The self that speaks in the preface," in Foucault's illustration, "is identical neither in its position nor in its functioning to the self that speaks in the course of a demonstration, and that appears in the 
form of 'I conclude' or 'I suppose'" (112). In what follows, I attempt to trace the different speaking selves of Kidlat, in the self that speaks at the outset of and prior to filming Bakit Dilaw?(1970s), the self that speaks in the course of making the film (1980s-90s), the self that speaks retrospectively about the film (2009), within the contours of nationalist-auteurist discourse but without the comforting finality of "I conclude," only the tentative presence of the author as "I suppose."

\section{THE CHARGE OF "THIRD WORLD" CINEMA}

That Kidlat Tahimik's films are "Third World" films is, of course, the source of his cinema's contested definition, a cinema that embodies the contradictions of representing Filipino identity onscreen mired in economic dependencies, sociopolitical upheavals, and neocolonial connections. It was the period of the martial rule of Ferdinand Marcos when Kidlat turned to the cinematic arts in Europe in the early 1970s. There was widespread violence and social unrest back home, as the Philippines sank more and more in debt and became the object of the US-maneuvered, IMF-World Bank politico-economic "restructuring" experiment. Far from it all, in 1974, Kidlat appeared onscreen performing the primitive, a village chief who plays on his nose-flute in order to keep his tribe alive, in Herzog's The Enigma of Kasper Hauser.

The contention for the meaning of "national development" vis-à-vis the Marcos government animated the year 1976 as a watershed in Philippine cinema history, with the release of Lino Brocka's Insiang, Mike de Leon's Itim (Rites of May), Ishmael Bernal's Nunal sa Tubig (A Speck in the Lake), Behn Cervantes' Sakada (Sugar Plantation Peon), Mario O'Hara's Tatlong Taong Walang Diyos (Three Godless Years), Lupita Concio's Minsa'y Isang Gamu-Gamo (Once a Moth), and Eddie Romero's Ganito Kami Noon, Paano Kayo Ngayon? (This Was How We Were, What Happens to You Now?). On the heel of these films came Kidlat Tahimik's first film, Mababangong Bangungot (Perfumed Nightmare, 1977). The Kidlat persona in the film is less certainly primitive, more decidedly naïve, and it clicked. To this day, it is his most discussed and remembered work, not least because its distribution passed through the US, with Francis Ford Coppola's Zoetrope. He was virtually unknown in the Philippines when it won three prizes atthe Berlin Film Festival (de Guia 105). As a bearer of the mark of independent cinema, Kidlat would remain unknown to the larger Filipino public for the decades to follow. For Mababangong Bangungot, as well as his other early films, did not have a ready place in popular cinema; it was shot in spaces not conventionally represented in Philippine film, starring unknowns, and using a film language foreign to mass audiences. Nevertheless, it also bore the foretoken of its milieu like the canonical films mentioned above, albeit as subterranean convulsions. 
Following the success of Mababangong Bangungot in Europe, and even with the precarious situation in the Philippines, Kidlat decided to resettle in Baguio City with his family. The decision to come home will have a direct impact on the way he will make his later films. The environment of violence that greeted Kidlat upon his arrival fitted well with the critical context that best animated his aesthetics the anti-auteurist discourse of Third Cinema (Solanas and Getino). From the late 1960 s to the early 1970s, at the time when Kidlat began his career in filmmaking,the anti-colonial and anti-fascist revolutions in Vietnam, Cuba, and Algeria have been inciting film makers to conceive of cultural production in more political terms. In such a context, intellectuals and artists of cinema outside of the Euro-American center of film studies began to call for radical film form and narrative through declarations and manifestos, most important of which were Brazilian Glauber Rocha's "An Esthetic of Hunger" (1965), Argentinean Fernando Solanas and Octavio Getino's “Towards a Third Cinema” (1969), Cuban Julio García Espinosa's "For an Imperfect Cinema" (1969), and Bolivian Jorge Sanjinés' "Problems of Form and Content in Revolutionary Cinema" (1978), which championed "sad, ugly films," militant documentaries, "low" cultural forms, and "imperfect" films. ${ }^{9}$ As American critic Robert Stam argues,

Most of these alternative aesthetics revalorize by inversion what had formerly been seen as negative, especially within colonialist discourse. [...] At the same time, these aesthetics share the jujitsu trait of turning strategic weakness into tactical strength. By appropriating an existing discourse for their own ends, they deploy the force of the dominant against domination. (32)

Kidlat's cinema may be understood in this context, but his peculiar deployment of the term "Third World" finds its meaningfulness if it is contrasted against the Third Cinema movement of Latin America. Kidlat's films, without exception, do not glory in ugliness nor do they build upon sadness and hunger. These ideas, on the contrary, are anathema to Kidlat's cinema. Moreover, all of his films, even those that lament injustice and violence, are premised on the hope of possible, though yet to be realized, triumph. His films are "imperfect," as Kidlat himself is wont to characterize it. Yet one of his most constant claims is that whatever "progress" has relegated to the realm of "sadness" and "poverty" is never really or should never remain self-referentially "sad" nor "poor." And the key to understanding this reversal, which precedes social change, is to transgress the bounds of the measures of "progress" that degrades. Hence, Kidlat appropriates the politico-ethical imperative of the label "Third World," but not necessarily the politics of Third Cinema with which Kidlat's films have been associated - at least not Third Cinema as conceived by Rocha, Solanas and Getino, Espinosa, and Sanjinés. ${ }^{10}$ 
Even nationally, his cinema, sui generis, occupies a separate space within the "aesthetics of poverty" which Filipino film artists have been forced to reckon with. In his films, Kidlat limns the beauty in typhoons, potholes, leaking roofs. Observers have noticed and noted this disposition. South African director, Ross Davenish, describes Kidlat's work as being "constructed like a cinematographic equivalent of a shanty town. Any material at all that can be used is. The result is tough, vital, simple, 'real' - an affirmation of life (qtd. in de Guia, 106)." American critic Patricia Aufderheide remarks that Kidlat's work is "a rare example of [...] film from a developing country about development that is executed with humor." His worldview is framed by possibilities instead of regrets, and so he emphasizes the uniqueness of Filipino culture, in spite of its inner contradictions. As such, his "Third World" films undermine the conventionally bleak image of the "Third World" framed by the "First World."

Kidlat's Bakit Dilaw? foregrounds how the film was imperfectly wrought out of junk, celebrating what Stam characterizes as Third Cinema's recourse to "the garbage heaps that, as both metaphor and synecdoche, inspired them" (29). The film opens with the panoramic wilderness of North America's Monument Valley, left breathtakingly beautiful but uncultivated by American "expansion westward." The clanging and thumping sounds of native Filipino instruments disconcertingly provide the score for the scene, as we see a lone kid, Kidlat's firstborn, playing with ragtag toy cars on the ground. By opening his film thus, Kidlat draws a parallel between the subjugation of Native Americans and Filipinos and melds their respective spaces through the images of Navajo land, the Third World in the belly of the First World, and the sounds of the Luzon highlands, the Third World back home which was plundered by the same First World that turned this Old West into a wasteland (Figure 1).

And then we begin to hear the boy, coached by his father's familiar voice, saying "In the land of plenty, junk gathers dust, or simply rust. In the land of not-so-plenty, wipe off the dust, and what do you get? A rusty Third World projector!" So the film opens - with jerk cuts, broken images, visual noise, and static, suggesting that though the film that is about to unfold is crude, the "Third World projector" will accomplish its mission nevertheless. By clinging to the term "Third World," Kidlat, like Michael Hardt and Antonio Negri, finds tactical value in "homogenize[ing] real differences to highlight the unifying processes of capitalist development, but also and more important, [in] nam[ing] the potential unity of an international opposition" (334; cf. Shohat and Stam 25-27).The translocality of Bakit Dilaw? situates it as a Third Cinema film addressed to the world, while, as we shall see below, it remains grounded on the specificity not only of the Philippine experience in general, but of Northern Luzon experience in particular. 

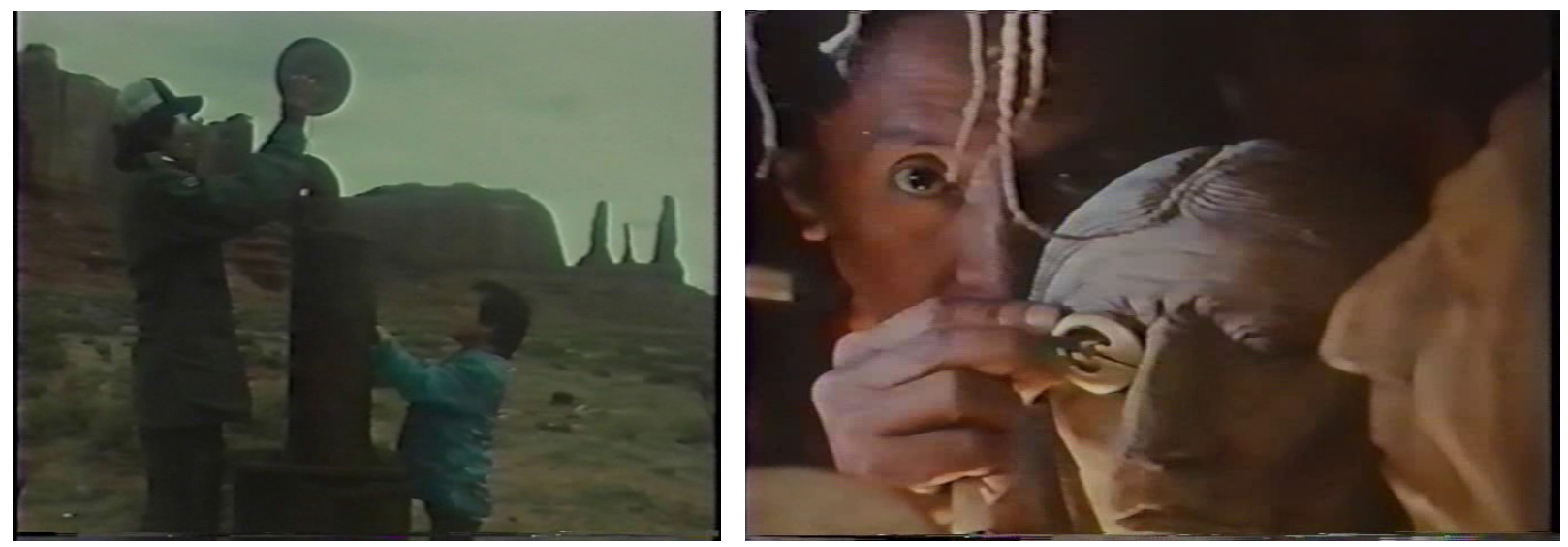

Figure 1. In his elaboration on the subjugation of Filipinos by Americans, Kidlat Tahimik alludes to the experience of the Native American Indians in the "Old West." From Bakit Dilaw ang Gitna ng Bahaghari?(1994). Screen capture by author.

Began in the early 1980s, Bakit Dilaw? brings to the fore issues on national politics which his previous films have left in the background. In one part of the film, Kidlat alludes to his sojourn to New York for the Robert Flaherty Film Seminar and his meeting with Brocka at the Telluride Film Festival, where the two discussed the growing conflicts in the Philippines and the assassination in 1983 of Senator Benigno "Ninoy" Aquino, then the strongest political opponent of Marcos ( $R$. Tolentino, "Kidlat Tahimik"). A brief comparison of these two filmmakers' works would serve to clarify Kidlat Tahimik's brand of "Third World" filmmaking.

Around this period, Brocka made two politically incendiary films, Miguelito: Ang Batang Rebelde (Miguelito: The Young Rebel, 1984) and Bayan Ko: Kapit sa Patalim (My Country: Gripping the Knife's Edge,1985), both starring popular stars of the time, Aga Muhlach, Philip Salvador, and Gina Alajar, in thinly veiled anti-establishment melodramas meant to be consumed by the mass audience. Meanwhile, Kidlat Tahimik, with Bakit Dilaw?, assumed the role of chronicler, a "man on the street" endlessly putting on record how "ordinary" folks were directly or indirectly responding to the times.

Cultural contradictions and political tensions are revealed to be half-hidden in minutiae. For instance, while Kidlat and his family are supposedly located far from the eye of the political storm in urban Manila, we see the inauguration of the replica of the Statue of Liberty in Baguio, where Kidlat's son is shown pissing; we witness how his firstborn son, also named Kidlat, is chosen to be Mr. USA in the annual school celebration of United Nations Day; or we watch the camera linger along Baguio's Session Road as demonstrators rally in front of a dilapidated signboard of Banco Filipino, with only the pieces that say "Filipino" (without "Banco") and 
"Subok ng Matatag" (Tried and Tested) are left intact (Figure 3). Such scenes are juxtaposed with snippets from television news about approaching typhoons and sounds from the radio blaring patriotic tunes. The details of the everyday add up to the big bind, Kidlat is suggesting, and the exorcising of the alien ghosts that have come to possess local culture cannot be accomplished with only one great heave (as he himself contrarily asserts in Mababangong Bangungot).

Brocka and Kidlat proceed along their respective filmmaking trajectories after the Marcoses flee and Corazon Aquino assumed presidency. Three years after the "People Power Revolution," Brocka released the graphically violent Orapronobis (Pray for Us, 1989), implicating the Aquino government in the maintenance of private armies and vigilantes in the rural areas, where these groups commit wanton violence and extra-judicial killings. Meanwhile, Kidlat continued to crank his camera to record the social discontent or apathy that went on during the Aquino administration, made symptomatically visible and symbolically poignant by the power crises and ten-hour blackouts, the massive earthquake that devastated Baguio, and the eruption of Mt. Pinatubo. In one scene in Bakit Dilaw?, Kidlat even comments on violence perpetrated by the Aquino regime in Manila, while he is in Baguio. His youngest son is asking Kidlat to bring the family to the movies to watch a "Rambo film," while pointing at the newspaper's upper-fold dedicated to the Mendiola Massacre on 22 January 1987. The headline reads: "Marines gun down Mendiola marchers; 13 killed, 16 injured." This front-page news was referring to how members of the Kilusang Magbubukidng Pilipinas (Peasant Movement of the Philippines), who were marching to Malacañang Palace to demand the agrarian reform that Aquino had promised, were shot dead by the military (Figure 2).
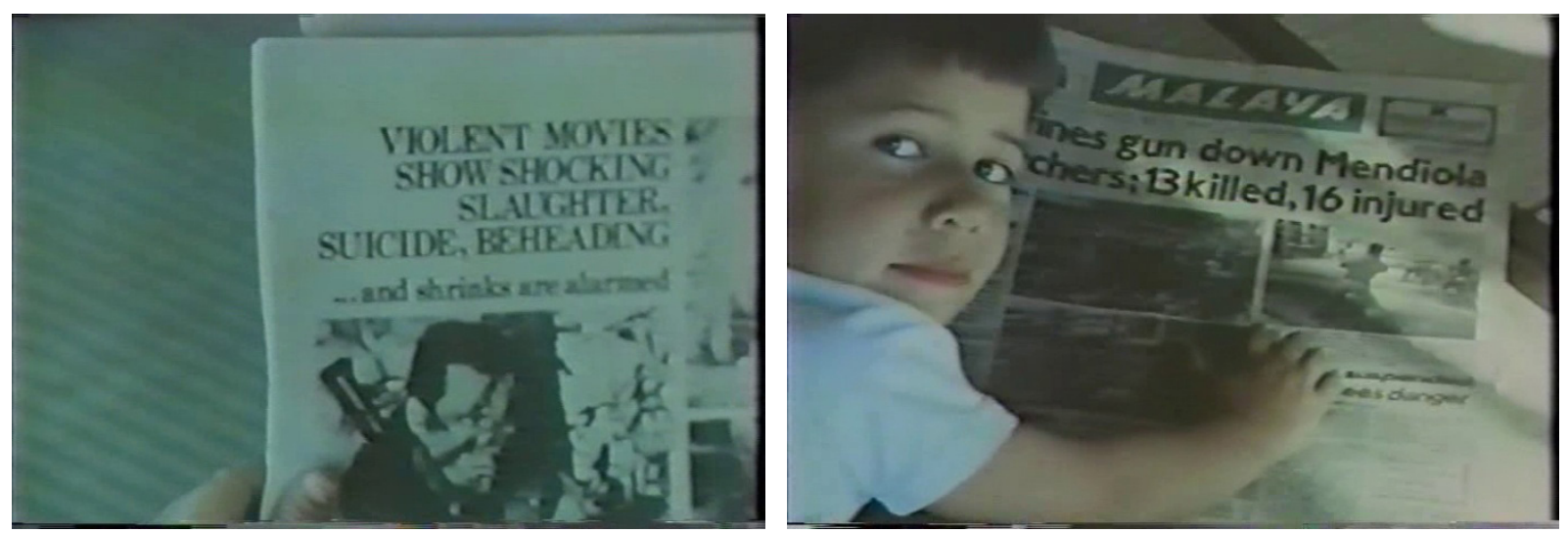

Figure 2. In a short scene, Kidlat Tahimik combines his critique of American influence on local mass media consumers and his commentary on the Aquino administration's human rights violations and unfulfilled promises. Reading the newspaper, his children are exposed to Hollywood violence that is taking over Philippine screens and the violence 
around them perpetrated by government, From Bakit Dilaw ang Gitna ng Bahaghari? (1994). Screen capture by author.
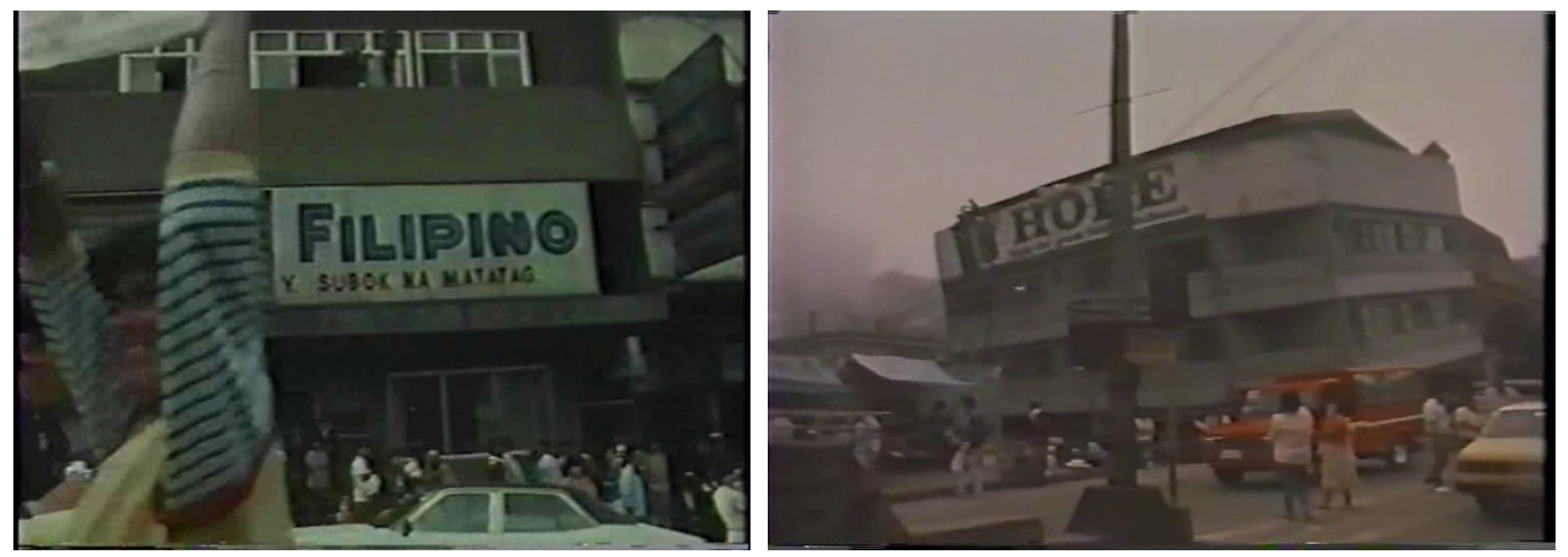

Figure 3. In Kidlat Tahimik's never-ending chronicle, images of natural and man-made calamities are interwoven and shown to either work against the Filipinos or serve to push them to assert their collective will. On the left, serving as a backdrop to an ongoing mass demonstration against Marcos is a broken signboard which announces that the "Filipino is tried and tested." On the right, the earthquake that shook Baguio during the Aquino administration is used by Kidlat as symbol of political instability, while showing how upheavals could spur people to work together and renew their "hope" on something larger than the government. From Bakit Dilaw ang Gitna ng Bahaghari? (1994). Screen capture by author.

Kidlat kept on expanding Bakit Dilaw?, until, as he describes it -

The yellow events [pertaining to the events that led to the fall of Marcos and the rise of Aquino to presidency] were no longer the climax of this never-ending documentary. While the film begins as a meandering kiddie album, it develops into soul-searching by the filmmaker tatay [father]. Interacting with his three sons, he tries to understand his own contradictions, originating from John Hay's 1902 MBA policy (Magnificent Benevolent Assimilation) and reaching until today's cultural lahar [the combination of floodwaters and volcanic ashes] - the colonial sedimentation from the TV's ashfall that threatens to bury the last unique contours of our indio-genius ways. (qtd. in de Guia 103)

Several Filipino critics have problematized Kidlat's romanticization of the "indiogenius" (a portmanteau of the pejorative "indio" with the terms "indigenous" and "genius") and questioned the way he has "exhibited" Filipinos to the world (David 69; Lim; R. Tolentino, "Subjectivity"). Because of the circulation and reception of Kidlat's portrayal of the "naïve native," the idea that Kidlat is unselfconsciously "primitive," as far as "First World" critics, notably Fredric Jameson, are concerned, 
has persisted (Jameson 210; cf. de Guia81-121; San Juan, "Cinema of the "Naïve" 272; R. Tolentino, "Jameson and Kidlat" 123).

Eulalio R. Guieb III likens the films of Kidlat to the 1887 "Rancheria de los Igorotes Exposicion de Filipinas" in Madrid and the 1904 "Louisiana Purchase Exposition" in Missouri. Both expositions, according to him, had one colonial objective: "[ipakilatis] sa mga diyos ng pagbabago ang isang natuklasang kulturang wala raw sibilisasyon [to allow the gods of progress to scrutinize the supposedly uncivilized culture that they have discovered]" (474). Moreover, he writes:

Tuwina'y istatiko ang pagdadaigdig ng mga pelikula ni Kidlat sa tradisyon at etnisidad ng mga mamamayan ng Filipinas. Ang tradisyon at kultura, batay sa mga pelikula ni Kidlat, ay payapa at tila talunang umaatras matapos ang nakaliliyong paglalakbay at pakikipagsapalaran nito sa malalakas na pwersa ng mga pagbabagong neokolonyal. Tumatalikod ang katutubong identitad sa larangan ng digmaang kultural.

[The worlding of Filipino tradition and ethnicity in Kidlat's cinema is always static. Tradition and culture, according to the films of Kidlat, are always peaceable, and they retreat after embarking on dizzying voyages and adventurous encounters with the powerful forces of neocolonial progress. The native identity seems to turn its back on the sphere of culture wars.](476-477; translation mine)

I do not wish here to absolve Kidlat of anything that the critics have charged him with, nor even to straighten out the critical conundrum that is nativism. Guieb's charge should suffice in demonstrating how any conception of the "native," once incarnated, and, more crucially, when beheld and substantiated, takes on the scandal of spatiotemporal situatedness and contingency. I wish to articulate, instead, how Kidlat, as someone whose lifestyle I have had chance to observe, along with the Kidlat that is continually being (re)invented in the rituals of his filmmaking practice, complicates the question of who the native is and how the native is determined. At any rate, his early films, because they have been consumed and lauded by Europeans and Americans, lend validity to the charge of orientalism. This is so, because at the heart of Kidlat's thematics and identity politics is the interfacing of the "foreign" and the "local" and a thoroughgoing comparison (and therefore a cleaving to the concepts) of the "West" and the "East," the "First World" and the "Third World," terms which have become critically problematic and discursively oppressive.

In most of his works, Kidlat begins with the presupposition that the Igorots have, in fact, had an advance culture even prior to colonial contact, have maintained this culture until today, and have continued to offer a model of cultural resistance for the contemporary Filipino artist. ${ }^{11}$ For instance, before I met him in 2009, Kidlat 
had just finished work on an installation for the exhibit entitled "Portraits de chaussures-Histoires de pieds (Portraits of shoes-Stories of feet)" at the Yuchengco Museum, for which he gathered the talents of 42 woodcarvers from the Cordilleras to create 180 pairs of bakya (wooden shoes), with each unique pair demonstrating "an exquisite curlicue, a Baroque detail, an engaging whimsy" (Zulueta). These creations were displayed side-by-side with 62 pairs from the seventeenth to the twenty-first centuries, collected from the Romans International Museum Collection and the French Fashion Houses Collections, and curated by Yves Sabourin. Consistent with Kidlat's stance as an artist, the surface of his concept is clear: Igorot artists are no less part of a creative dialogue that has been ongoing for many centuries all around the world. The process of the work is oppositional: each pair of bakya, a kind of shoes that has been associated with lowbrow taste, is stamped with individuality and not uniformly mass-produced. Hence, where Guieb faults Kidlat is exactly where Kidlat locates himself, the point where the native is called to return to a culture resisting change, in spite - or precisely because - of the colonial technologies that have made possible the 1887 and 1904 expositions that exhibited the Igorot as backward, hence changeless. And it is exactly in their presuppositions about "stasis" and "change" that Guieb and Kidlat differ.

With reference to Kidlat's cinema and his portrayal of the Igorot, Guieb writes:

Tinutugis tayo ng nakaraan, inaaway tayo ng nakaraan, hindi pa dahil sa hindi natin ito nililingon kundi dahil patuloy nating ikinukulong at ikinakahon ang nakaraan sa kanyang nakaraan. Finofossilize natin ang nakaraan, ang katutubong tradisyon at kultura, na para bang hindi ito marunong makipagdayalogo sa kasalukuyan. Ang pagkaladkad sa nakaraan ay nangangahulugan ng pagsasangkot at pakikisangkot nito sa tunggalian ng mga diskurso sa at ng kasalukuyan.

[We are being hounded by the past, hunted down by the past, not even because we have not looked back to it but because we have continually tried to imprison it, to box the past in the past. We are fossilizing the past, indigenous tradition and culture, as if it does not know how to dialogue with the present. To drag the past means to implicate and involve it in the struggle of discourses of and in the present.](477-478; translation mine)

In short, Guieb asserts that Kidlat has caged indigenous culture in the past, by portraying it as static and anachronistic. Meanwhile, Kidlat — film after film, progressively from Mababangong Bangungot-has been laboring to show Igorot culture as alive at present. By assuming so, Kidlat is insisting that those who find highland culture "primitive" is mistaken, for it is what it is because it has resisted in subscribing to the measure of progress imposed by the colonizers. Urbane lowlanders have found the Igorots "deplorable" for "failure" to accept Spanish 
culture (Scott, Of Igorots 55; Aguilar); white people have denigrated and despised them for their "lack of progress"; and for these very reasons Kidlat asserts that there had been and still is active cultural resistance, which means that the resistance is ongoing and must go on at present.

Guieb sees Kidlat as dissolving the present in an unchanging indigenous culture, while Kidlat sees his own project as resolving the epistemological violence of the past inflicted on the Igorots into a present and living culture. Guieb laments the view of Kidlat's cinema as a kind of instrument for nostalgia of things past, while Kidlat sees the abiding aspects of a determinate historical and geographical "native" culture as the very condition for the possibility of still defending it. Kidlat's project is not indigenization and may not even be recuperation of indigenous culture, but the protection of a living culture from complete obliteration. As such, the continuous self-references to his own contradictions in his films is an admission that the culture he is representing is no longer "pure" in the nativist sense. His use of the English-language in the voiceovers and in his conversations with Igorots is a testament to this, which parallels his use of the motion picture technology in the mountains. That he keeps making such films suggests that he finds that this culture in question is, at present, being threatened. The terms of Guieb and Kidlat, cast in this way, are somewhat symmetrically opposed, though I think that both of them (contrary to Guieb's reading of Kidlat) share the same idea that culture should be perceived as "ways of struggle" (Guieb 477).

I agree with the implications of Guieb's critique that the rhetoric of Kidlat would demand a kind of extreme praxis the (impossible) realization of which would result to stasis. This demand, therefore, is untenable. But what is remarkable, upon observing Kidlat in Hapao, is that for him, apparently, the whole idea of the efficacy of native cultural resistance is not merely rhetorical (though it is, too), wielded by intellectuals in theory, and that he is willing to commit himself to living it out in practice. It is remarkable, too, that while Kidlat interchanges his identifications of "Igorot" and "Filipino," he never - in his films and in our conversations - insists on applying, as it were, an Igorot cultural model on any other Philippine region.

It is Kidlat's grounding, chronicling the events in Baguio City and Ifugao, rather than any comment on the "nation" and a homogenized image of miserable and hungry "Filipinos," that further differentiate his project from that of Brocka. In this sense, Kidlat has been filming from the regions without the benefit - or limitations - of the now oft-used term "regional cinema," institutionalized in 2009 by the state-supported film festival, Cinema Rehiyon, and without the burden of attacking or differentiating against the Manila-centric film industry (cf. Co). The situatedness of his cinema, moreover, renders heterogeneous "Third World" space, 
which "First World" critics such as Jameson, according to Aijaz Ahmad, tend to deleteriously homogenize.

Like Guieb, Christopher Pavsek, in his compelling book, The Utopia of Film (2013), detects the possible problems of Kidlat's "nostalgia" as celebrations of older ways of life that are "simply impossible to resurrect" because the "ontological ground for those practices has changed." Pavsek deflates this essentialist tendency, through his reading of Kidlat's early films, Mababangong Bangungot and Turumba(1983), by distinguishing Kidlat's project as an "imaginative translation [of the past] into new contexts, an abstraction out of the initial, core historical experience into the new contemporary situation," enabling the imagination of new futures (ch.2). San Juan, on the other hand, offers a reading of Kidlat's cinema which plays down its Igorot cultural aspect in order to characterize Kidlat's work as a nativist "strategy"and a kind of Fanonian prelude to revolution ("Cinema of the "Nä̈ve" 268, 275). These readings of Kidlat attempt to activate the revolutionary-utopian dimension of his cinema, but, in the process, they explain away Kidlat's unrelenting anchorage on Igorot culture which is literal, specific, and committed to the present.

The utopian Kidlat is intractable and not simply reconcilable to an abstracted revolution. Pavsek rightly concludes that Mababangong Bangungot and Turumba "do not really figure any sustained future, any reconstituted society that will appear in the wake of the revolt" (ch. 2). But beginning with Bakit Yellow? and especially with his later film essays, Kidlat offersan image of a lived life in Ifugao not always as a polemic but as a model of a possible social dynamic that invites hard questions about the particularities of praxis after a revolution, although as a life lived out against the onus of global social order now.

While Kidlat's life-choices as a filmmaker may have proceeded from a tendency toward "abstraction" and "nativist strategies," as best exemplified by Mababangong Bangungot, his body of work can be understood better as dynamic films-of-becoming that enliven his struggle to move away from these abstraction and strategies. As such, each of his films is a temporarily fixed embodiment of identity at a given time, meant to be (de)constructed in the succeeding film, making every film like genre films - similar and yet vitally different. And, indeed, the tentativeness of their repetitions and the unfinished quality of Kidlat's films foreground their constructedness and lend themselves to such a reading. The self-reflexive Bakit Dilaw?, filmed over a period of a decade, serves as a marker of Kidlat's departure from his earlier works (though it was begun concurrently with these earlier works).

Bakit Dilaw? is like the earlier films in the way that it has been left to gestate until it reached a more or less finished form. Mababangong Bangungot was begun in 1975 and finished in 1977. Sino ang Lumikha ng Yoyo?Sino ang Lumikha ng 
Moon Buggy?(Who Invented the Yoyo? Who Invented the Moon Buggy?), a littleknown sequel to Mababangong Bangungot, was started in 1978 and finished in 1981. Turumba, which is popularly known as his second film, began production in 1981 but was only released in 1983. Around the time of the release of Turumba, he began Takedera Mon Amour and concluded its production only in 1988, near the time of the first release of Bakit Dilaw?, whose earlier and shorter version was entitled I am Furious Yellow (1989). ${ }^{12}$ These four early films, indeed, suffer by degrees for their insistence that native culture must remain unchanging.

But Bakit Dilaw? crystallizes the cinema of Kidlat Tahimik and fleshes out the contours of Guieb's problematique: that there is a gap between the reified text and the dynamism of praxis, between the image of the auteur and the fluidity of his process, and between individuality and socio-cultural identity. Kidlat, in spite of the ritualistic redundancy of his films, is not repeating his works exactly, as one cannot repeat a performance in the same precise way. Moreover, Kidlat is not any one of his films but all of his films understood dialectically. As sociologist Randolf David describes Kidlat's cinema, "It's the journey of making the film that matters. $[\ldots]$ The process is the person [...]" (139).

As text and praxis, Bakit Dilaw? incarnates Kidlat, whose identity performance is conflated not only with his screen personage, but also with his concept of the "native" and the "collective," and typifies his mode of reenacting journeys and homecomings, resulting in varied conclusions. Unlike his earlier films, Bakit Dilaw? is an explicitly historical-critical work that is more attuned to national concerns, while it also foregrounds as process the shifting political concerns of the artist. It is a panorama from below ${ }^{13}$ that gives an account of the vicissitudes of a nation in the process of self-determination against imperial and global capitalist forces, but, at the same time, a testament to the reality that the "peaceful revolution" of 1986 did not change anything. Hence, when Bakit Dilaw? was first released as I am Furious Yellow, it was a celebration of People Power, portraying how Kidlat and his family supported the "yellow revolution" of Corazon Aquino. But when it was revised and released again years later, it was transformed into a statement of defiance, for it was now clear that Aquino's promises regarding economic, political, and cultural liberation, land reform, and decolonization have been betrayed.

Even during the screening of Bakit Dilaw? in Japan in 1994, as Kidlat recounts to us in one long-winding conversation in Hapao, his performance included the physical excision of some inches of celluloid from the reel (perhaps indicating the violence of state censorship?), to the astonishment of the audience. Bakit Dilaw? demonstrates how a film - or a person's cinema-is never complete, especially if the extra-filmic reality it struggles to circumscribe is also in a state of flux. 
Such a point-of-view engendered an ironic position for Kidlat's cinema and for himself as an artist up to that point in the early 1990s. On the one hand, his cinema and his notion of identity connoted an ongoing process, materialized by the performances and celluloid records of an individual middle-class artist. On the other hand, his struggle with the stigma of Third World-ism predisposed him to anchor the process of identity-formation and representation on the collective aspect of native culture that he has come to avow as ultimately resistant. The quandary of these questions of identity, representation, Third World-ism, and the drive for national liberation is punctuated by Kidlat's ongoing refunctioning of "Third World" in Bakit Dilaw? In the opening of the film, we hear this exchange between Kidlat and his son on the audio track, while we are watching a group of men carrying a heavy log across the forest and then commencing to build a hut.

SON: What means [sic] "Third World"?

KIDLAT TAHIMIK: In America, Japan, and Germany, it is mainly machines at work, like bulldozers, earthmovers. Here, people power moves things.

SON: Uhm, "Third World” is "people power"?

KIDLAT TAHIMIK: More muscles, with less help from machines. You know "Third World" is a way of life, a road, a route, for surviving without wasting. "Third World" means more reliance on your own energy, instead of artificial energy like electricity. The more dependent you are on your own strength means more independence. If you chop wood by hand or by power-saw, this affects the way you attack your bigger problems.

SON: "Third World" is a way of solving problems?

KIDLAT TAHIMIK: Yes. "Third World” is a way of solving problems.

These exchanges indicate Kidlat's implicit argument regarding the authentic dynamism of labor force, but it is very easy to dismiss as a kind of regressive discourse that espouses stasis and backwardness. Turning our backs, on the efficiency, comfort, and pleasures of technological "advancement" will result in "regression"; but this is also a practical critique of what Kidlat calls "overdevelopment," which has put more importance on expansion, accumulation, and production (i.e., imperialism and capitalism) rather than humanity.

The aforementioned exchange between Kidlat and his son finds its echo later in the film, when Kidlat introduces the village chief and woodcarver, Lopes Na-uyac, in a scene of constructions. The images of mountains and the vast river render the 
human figures in the scene diminutive; these figures are walking against the rage of the current, building a dam across the waters and a bridge to span the mountains. The audio track that accompanies this scene now does not merely idealize "primitive" and "Third World" ways; Lopes and Kidlat, in their voiceovers, now contextualize these constructions in light of an inutile government. Moreover, Kidlat's framing of the Ifugao culture here is propped up by a theme that cuts across all of his films - that American-style modernization has wrought violence on traditional values and institutions, marginalized what was considered culturally vital by "premodern" Filipinos and rendered them "primitive" and "inferior." Hence, in such a framing, Kidlat's accounting of the shortcoming of the state extends to a historical critique. Lopes, in the aforementioned scene of constructions, tells Kidlat onscreen,

LOPES NA-UYAC: We people in the mountain, we cannot live without bridges. So we have to make bridges [...], because there is no government bridge; so we depend on our own initiative. Just like the rice terraces, there is no government engineer [...]. Well, you see, [...] since we are building the bridge out of vines, it does not last so long. So to make the bridge, we also have to build a dam [...] so in case of emergency, we have the water to save lives [...].

This is "Third World," Kidlat is saying in Bakit Dilaw?, the resilience, selfsufficiency, and wisdom of a people. And he contextualizes it for his son, in a line of dialogue which alerts us of Kidlat's self-consciousness about exoticization of Igorot culture and the problems of orientalism. He tells his son,

KIDLAT TAHIMIK: It's tragic that our government in Manila sees them [Igorots] only as tourist attractions. They [the Igorots] join us in our call for justice for Ninoy, but they're more concerned with the loss of their ancestral lands [...], so that they are fighting injustice as they had in the [colonial] past to preserve their way of life.

\section{KABIGAT, NATIVE OF IFUGAO}

"Something attracted me to Lopes," Kidlat tells us, in Lopes's presence, over a jar of tapuy [rice wine], one evening. "I could feel his tribal leadership. He had an inner auto-drive to solve problems with whatever resources, whatever instincts he has. I remember there was a strong typhoon once. There was a road cut. Lopes stirred the bayanihan spirit [spirit of solidarity] among the people. Without waiting for Big Brother, for City Hall, for any manual, they made the way passable again."

"I followed him back to his village," Kidlat continues wistfully, as if thinking of a home he sorely misses. "And I discovered the ancient wisdom of the tribe. Lopes was reviving the old pinugo practice of maintaining the small forest on top of every 
rice terrace system which would assure constant water, 24 hours a day, 365 days a year. This has worked for over 3,00o years, non-stop. This is where I think the indio-genius is so clear. Lopes isn't an ilustrado, but he's connected. He is proof that we can combine the modern with our native culture gracefully. Ang galing $n g$ Pinoy. Matuto lang ulit tayong makinig. [The Filipinos are remarkable. We just have to learn to listen again]."

And Kidlat, as far as I could see, is listening. The critical conundrum of "nativism" finds another layer in his willful struggle toward his own "native" selfdetermination. It is so easy, I realize, to valorize the idea of a native self. But this struggle, for Kidlat, is a practical struggle, though he would rather make us believe that it is not a struggle. I learned that in Hapao, where he now spends most of his time, he commutes by ragtag bus and jeep if he needs to travel some great distance. He treks up and down muddy mountain slopes for stretches of time to get from one neighbor's hut to another. He has limited access to electricity and no access to the Internet. There are no convenience stores nearby and no department stores for miles. His meals, which he shares with us, are simply flavored. The rice that he eats, he himself must plant and harvest, with the help of the community. He is not some fanatic nativist who is trying to stop powers-that-be from paving highways and supplying day-long electricity in these parts. The urban-center has marginalized these mountains without any help from him, except as far as tourism goes. But Kidlat is asking us if he is any poorer if he cannot watch television, put artificial seasoning in his vegetables, or wear the latest fashion.

Lopes, too, holds Kidlat in high regard, not because of his MBA [obtained from the Wharton School of the University of Pennsylvania], but because "he eats what we eat," he says. "He helps during the planting and harvesting seasons, with his sons. He goes to funerals. He is always thinking of how to improve the lives of people in the mountains and how to preserve our culture." Says Lopes, "Kabigat is like a father to the people of Ifugao," even doing - quietly - what the government should be doing, like shelling out his own money to improve the irrigation system of the terraces and to increase the harvest by doing research and experiments on organic fertilizing. ${ }^{14}$ Lopes is describing Kidlat's efforts toward sustainable development, equity, and conscientious use of and care for the environment - efforts that are largely overshadowed by the identity-politics that Kidlat foregrounds in his cinema. These efforts give a more complete picture of how identity, representation, and agency come together in Kidlat's brand of independent art-practice.

"Why am I so interested in these people who built the rice terraces?" Kidlat is explaining to us the roots of his love affair with Ifugao. "Because they're more intelligent than Albert Einstein? Hindi ito pataasan $n g$ ihi [This is not a silly contest]. It's just that they've exhibited a certain genius, even before colonial forces 
have subjugated the local culture and turned us into indios. In this troubled world today - what Al Gore calls the 'inconvenient truth' - people from the West are recognizing why the world is not sustainable, why the world can't reach a peaceful coexistence - because we've ignored the harmony between nature, the spiritual world, and humanity. We have followed the path of greed to accumulate and forgotten our cultural preno [brakes]. Westerners have accepted that material comfort is the be all and end all of life. But now they're asking, 'Am I really happy?"

In Bakit Dilaw?, Kidlat presents the pageant of proud Ifugaos in bahag during a harvest feast, marching along the rice terraces carrying red flags. In the audio track, Kidlat declares, "The Igorots have resisted foreign domination for over 500 years." Historian William Henry Scott regrets how Philippine textbooks have largely ignored how "these mountain peoples fought [the colonizers] for their liberty with every means at their disposal for [hundreds of] years, and this resistance was deliberate, self-conscious, [...] continuous [and] largely successful" (italics mine; "Igorot Responses" 182; cf. Scott, Of Igorots1-39; D. Tolentino). Scott laments, moreover, how

Modern writers of the Republic of the Philippines have been almost as slow as their Spanish predecessors to give credit to the Igorots for this defense of their territory, and lecturers in college classrooms in the nation's capital have been known to dismiss the accomplishment as a simple accident of geography or international politics - that is, that it was too much trouble for the Spaniards to invade the rugged mountains or that they didn't want to do so in the first place. [These are] flatly contrary to the historical record. ("Igorot Responses," 189)

He writes, in the same essay, "Certainly the Igorots left no record of following the counsel of Spanish friars either blindly or otherwise; quite the opposite, the friars described their obstinacy as monumental" (194). And he adds: "such an attitude [...] was not restricted to traditional religious values alone. From the voluminous unpublished manuscripts of that eighteenth-century Dominican authority on the Igorots, Fray Francisco Antolin, it appears they were able to maintain this same beady spirit of independence in their own way of life" (196).

Today, much of the Cordilleras remain removed from the political center, marginal to mainstream economic development, and relatively unreached by western-style education. By such measures, the Igorots are a disenfranchised minority (Anderson 329-330). But with Kidlat's Third World-ism and rereading of history, disfranchisement is recast as resistance, self-reliance, and the keeping alive of the possibility of sustaining an independent culture. 
Kidlat's celebration of the independence of Igorot culture speaks of his personal and social crusade as an artist, and it is the dynamics and progression of this crusade that must be precisely qualified. Kidlat's early films feature a naïve hero played by Kidlat himself, fanciful narratives with historical underpinnings, and a latent drive for grandeur. Mababangong Bangungot tells of the defiant if impossible return of the native from Europe back to the Philippines, paralleling Kidlat's own journey from studying in the US and working in Europe and to his coming home to Baguio. Sino ang Lumikha ng Yoyo? is about the travails of a man who wants to create a space shuttle out of farm junk, with the help of playful children, so the he could play yoyo on the moon..$^{15}$ The vanity of Sino ang Lumikha $n g$ Yoyo? is capricious; the same naïve figure from Mababangong Bangungot endeavors to fly to the moon and restore the innocence (that is to say, to critique the imperial and patriarchal drive) of desiring to land on the moon. At one point in the film, Kidlat muses: "The moon is no longer a virgin. Men have driven their cars all over her, rock collectors have picked from her. I wonder if someone has played a yoyo on the moon." Considering these films as Kidlat's grand gestures (consider, too, the films' narrative conclusions) and projects of conceit, one can agree with San Juan that Mababangong Bangungot is, "in historical context, an allegory of the Filipino artist's claim to recognition" ("On the Cinematic Art").

But in Bakit Dilaw? Kidlat is no longer figured as a returning hero who takes up the cause of a powerless people, in order for him to represent them on the world stage ${ }^{16}$ In the film are intimations of how Kidlat began, at first cinematically, to identify himself with the Ifugao. Beginning with Bakit Dilaw? onward, his films no longer attempt to stand for the marginalized Igorot and to rectify the errors that Scott calls out. Conversely, he has begun instead, as he confesses in Bakit Dilaw?, to draw upon the independence that Ifugao culture represents. It is as though Kidlat is actualizing his cinema with energy borrowed from an indigenous cultural domain that appears impervious to colonial influence (cf. Chaterjee 237). From Bangungot to Bakit Dilaw?, we see Kidlat returning from "the West" to "the East," gravitating toward his indigenous roots, so that whether he finds himself in the Old West or in the Himalayan mountains, or anywhere else, we learn through the films that he dreams of Ifugao. In Bakit Dilaw?, the fascination with the culture of the Ifugao is promenaded. In his later film essays, we learn that Kidlat has literally moved from Baguio to Ifugao. In this way, the dialectics of subject-formation is borne by Kidlat's cinema, which is his mode of self- and cultural-production. Remarkably, his cinematic trajectory, paralleling his physical and homing journey, is the same movement that the Igorots took upland, toward the most rugged of terrains, in an interior which they could navigate, in their effort to resist the colonizers (cf. Canilao 34).

In Some More Rice, Kidlat speaks of the more personal dimension to his crusade:

Kritika Kultura 25 (2015): -081 
KIDLAT TAHIMIK: Our rice paddies here in Hapao are a quiet mirror of the clouds and the blue sky. I moved to this village two years ago, tired of the city. I built my own hut to reconnect with the rice cycle. I'm here more because I want to learn from the Ifugaos.

In the same film, he tells Mr. Takahashi:

KIDLAT TAHIMIK: One small spring waters so many hectares of rice terraces [i.e., the pinugo]. Even if my sons will not become rice farmers, I ask them to help [during harvest season], just like other Ifugao children who return home to help their elders harvest. Ah, Mr. Takahashi, I invite you to my village to witness the community harvest. You might still have memories of your father's time, the energy of the collective.

Speaking here, long enough, is the Kidlat wearing bahag, performing the Ifugao by finally being one, trading his polemics for an autobiographical claim to notions of "independence" and "art" that are both about the individual and about the community. In the early years of his film career - in Herzog's Kasper Hauser and Alfred Yuson's Shaman Wars (1982) - he had worn the bahag for the sake of cinematic fiction. He has now entered the cultural domain pictured above, the community that he has located and redefined to fit himself in, through his cinematic rituals, so that he could speak not only about it in his films but to speak and to film from within it. He now does not identify himself with Ifugaos but as an Ifugao.

Kidlat tells us that he has received his "green card" and has been adopted as a son of Ifugao. His hut is rooted in the property of Lopes's late father, Kabigat (which is also a name of a minor deity), so the locals call Kidlat, Kuya Kabigat. Upon our arrival in Hapao for the first time, we get to meet Lopes himself, and I could tell quickly which part of him is not his screen persona. In any case, here he is, with no lines of dialogue to recite before the camera. Kidlat introduces us to his "bahag-brother" and "mentor" with tenderness; they are both of them so much older than their screen selves in Bakit Dilaw? (Figure 4). I become privy to the closeness of the two with each other, a closeness not immediately perceptible onscreen ("Midlife Choices" 48-49). 


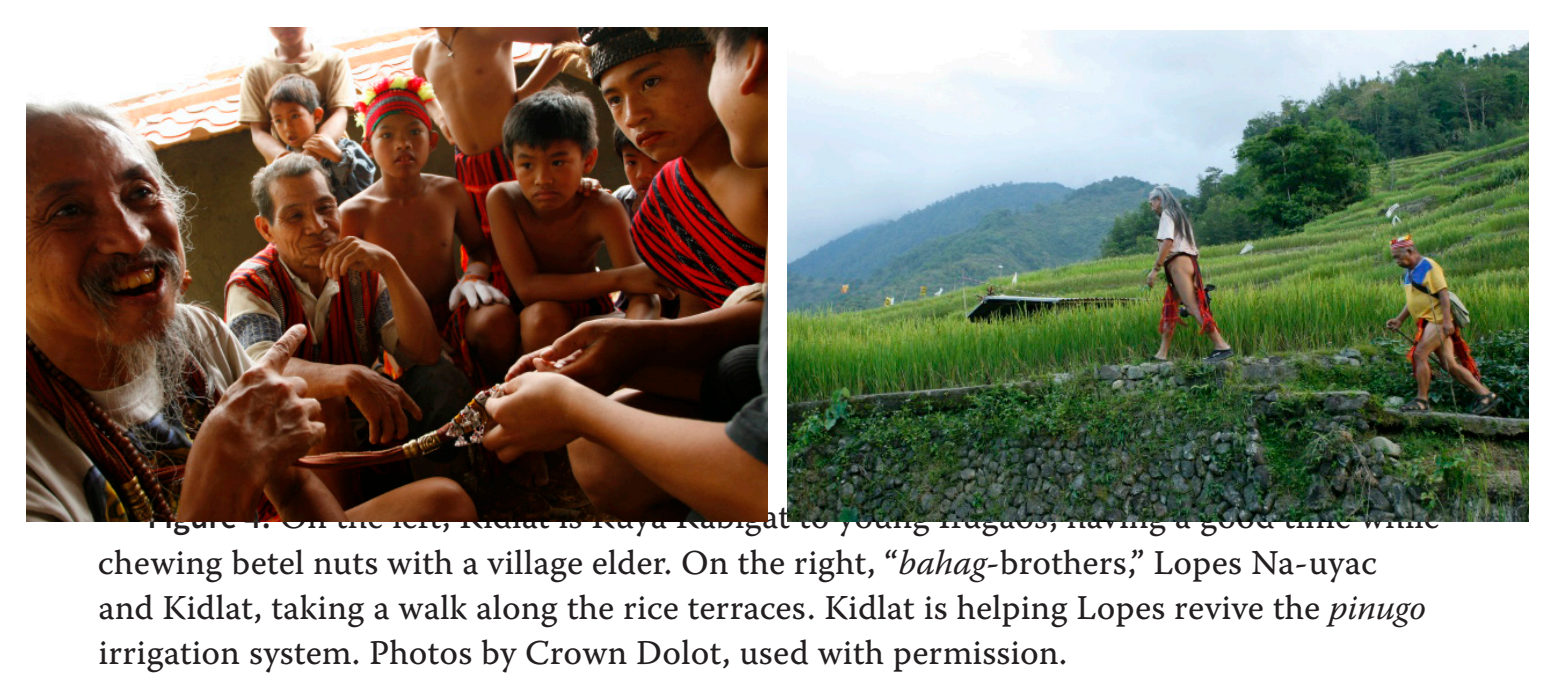

The advance in his age is more felt now, as Kidlat voices out his thoughts about being an artist. In a thoughtful conversation in Hapao over a lunch of freshwater fish and red rice, he turns the title being ascribed to him, the "Father" or "Godfather" of Filipino indie cinema, like a pebble in his hand. ${ }^{17}$ "It so happened that I came earlier," Kidlat tries to convince us, and maybe himself, too. "If I had come later, Raymond Red or Rox Lee could just as easily have been 'the father of indie cinema.' It's just that now I'm already a lolo [grandfather]." But it is easy to forget that he is old. As our team climbs down one mountain and up another to get to his retirement hut, our knees shake and our lungs almost give out. But there he is ahead of us, strolling with a stick like a wizard in a park, pointing his camera at us and chuckling. "If half of my batch mates could live like this," he interjects, "I would be so happy!" And as the locals congratulate us for trekking the "eighth wonder of the world," Kidlat quickly corrects the phrase and says, "The first!"

Many years before moving to Hapao, Kidlat had already recognized the thorny politics of representing indigenous peoples. In the 1980s to the 1990s, through his Sunflower Film and Video Collective, he introduced the Ifugao people to video technology, gave them access to cameras and, later on, laptops for editing, so that the locals themselves could preserve their own culture by documentation. ${ }^{18}$ Kidlat's desire to empower his Ifugao community with the technology of filmmaking does not only imply his understanding of the problem of representation but also his relinquishing of authorial ownership of the image "the Ifugao" on which his reputation as independent Filipino auteur partly rests. The move toward communal art-making defuses the urge to inquire about the authorial function of artistic texts, an urge that implies the drive toward individualism and private property, and emphasizes instead the ancient value of anonymity and collectivity (cf. Foucault 108-109). 
Self-reliance has been a refrain in our conversations, tucked in between Kidlat's reflections on rejecting foreign aid and initiatives by Ifugaos to solve their own problems without external prodding. In this vein, his notion of independent filmmaking as self-reliance correctively exceeds the narrow comparison between mainstream and indie films and the conventional portrayal of the individual artist as being separate from his community. Kidlat saw early on the potential of democratization brought about by video technology not in the terms dictated by commercial cinema or even art cinema. He saw the portability of the new technology as making possible a communal approach to filmmaking and as a means of restoring the emotional charge of community life that has dissipated through time. He saw the technology for its capacity to serve the indigenous community beyond the highly regulated conditions of indigeneity imposed upon it by outsiders, including himself, who try to represent the community (cf. Casumbal-Salazar).

Like folklore, "this [local filmmaking] is the oral transmission that we need," Kidlat explains to us, while he is taking a break from filming the bone-burning ritual. "We're always talking about — sino'ng pinatay [who was murdered], who went to bed with which star? We're not giving enough column inches or airtime to things that have to be told and retold. That was the old way - oral transmission before television and radio and print took our minds into another planet, a more irrelevant planet."

Through Kidlat's efforts, the elders of Hapao are now documentarians and photographers, beginning with Lopes, who, as a tribal leader driven by a desire to chronicle village life, enrolled in one of Kidlat's workshops before. Little wonder that in this bone-burning ritual, there is not only one filmmaker-in-bahag shooting the ceremony, but several others, young and old. Santos Bayucca, one of Kidlat's Ifugao confidantes and filmmaking mentees, tells us that he documents cultural activities in the community, so that he could show these materials to his own children. He tearfully adds that he is all the more encouraged to keep filming whenever Kidlat praises his shots and framing (De Guia, "Bathala Na!" 94). In the evenings of our stay in Hapao, when the supply of electricity is more stable, Ifugao teenagers in modern garb use Kidlat's Apple MacBook to do nonlinear editing on a Final Cut platform.

Kidlat considers this communal project of filmmaking pressing, because he is concerned with the young people of Ifugao who desire to move to overpopulated Baguio to become peons. An immediate result of such a mindset by the young would be the ruin of the rice terraces and their corresponding life-cycles. By awakening in them the capacity for art, for filmmaking and editing, for documenting their heritage, Kidlat says that he"hopes to awaken in them their sariling duwende, their identity as highlanders and as Filipinos." Kidlat claims that the Collective's 
"long-term goal is to neutralize a feeling of shame about what the Ifugao have been told is a backward culture" (qtd. in de Guia, 117). Perchance, these young people will no longer think of themselves as "poor" and "backward" and will decide to stay to cultivate and continue to enrich the land.

Many scholars have written on folklore and the native self buried therein, waiting to be unearthed again. And then here is Kidlat before us, chewing betel nut with the elders, singing a thankful melody that farmers sing after a good day's work, and telling us that this culture is not buried in some past but is here now. ${ }^{19}$ Obviously, Kidlat is struggling uphill against time, for modernity and progress have rendered what he considers as present anachronistic. I think it is crucial to see him as struggling, for he would otherwise not be making his films that way he makes them. Being an independent Filipino artist is no mere platitude, and the auteur must always be exceeding his effect.

As with his quixotic cinema, the direction he has chosen for himself is singular, no matter his insistence that this is where we should all be at. In this particular sense, Philippine cinema does not need another Kidlat Tahimik. His romanticism of native agency is disputable, and I do not always agree with him. But his predisposition offers an alternative discourse of independence in cinema that cannot be separated from an independent determination to become and to live it outbeyond cinema. However he has defined himself, Kidlat has clearly possessed the boldness, against the odds, to do what he claims he should $b e$. And it is only with the same zest for life and bravery to do as I believe I should, that I can thoughtfully disagree with him. This, I have found, is his daring and his dare, and he is challenging me to agree or disagree, with no schism between thought and action. 


\section{Notes}

1. The documentary on Kidlat Tahimik referred to in this essay, which allowed me to do participative observation and extensive interviews on his life and works, was principally shot in May of 2009. It was screened in July of the same year, when the Gawad Plaridel Lifetime Achievement Award of the University of the Philippines was bestowed on Kidlat Tahimik. The research involved in the making of this documentary, which I wrote and edited, gave me the opportunity to interview not only Kidlat, but also, among others, his wife, Katrin de Guia, and his sons, Kidlat, Kawayan, and Kabunyan; his Ifugao confidantes, most notably Lopes Na-uyac and Santos Bayucca; independent filmmakers and cultural administrators, with whom Kidlat has had personal and institutional dealings; members of the Baguio Arts Guild; Baguio and Ifugao artists, young and old, to whom Kidlat has acted as benefactor through the years; and Kidlat's neighbors in Hapao, Ifugao. The interviews, as well as the extended conversations with Kidlat, were conducted from March up to June 2009. During this period, the production team lived with Kidlat in Hapao and Baguio City for nearly two weeks, observing and filming his home life, interactions with various people, and creative process. This kind of research framed my critical engagement with Kidlat's cinema, which at this time was preoccupied with the general question, "What is independet cinema?" I returned to his films, as well as critiques of his films, from a perspective inseparable from lived experience, this time allowing the reflective "I" more space in my criticism.

Statements by and information on Kidlat in this essay, especially of the autobiographical sort, are based on our interviews and conversations, unless otherwise noted, and are expressed here filtered by my own reflections. Four other important sources on Kidlat's life and career, as well as elaborations of his aesthetics, are by Kidlat Tahimik himself, namely "Cups-of-Gas Filmmaking vs. Full-Tank-cum-Credit Card Fillmaking"; "Midlife Choices: Filmmaking vs. Fillmaking"; and "UP Gawad Plaridel (2009): A Multimedia Lecture"; and a biographical account by his wife, Katrin de Guia, "Bathala Na! In the Spirit of the Ancestors." Referring to these sources, one immediately notices repetitions of ideas with minute variations. I hope these partly validate my assertion about Kidlat's ritual self-(re)invention, as these same ideas are played out and exemplified in his filmmaking practice.

2. For news on this bone-burning ritual, see Palangchao.

3. The auteur theory has been seriously challenged most significantly by poststructuralists who have "[rejected] the notion of authorship as a repressive principle of interpretation" (Thomson-Jones 42;cf. David; Staiger and Gerstner; and Maule). 
4. Kidlat's uneven regard for the US and Japan is politically complicated when his cultural critique is made in the realm of or even seeks to impact historiography. The idea of sending back bombs turned into bells to former enemies as a symbol and a gesture of peace, in a film that alludes to the atrocious conflict between Japan and the USA, essays Kidlat Tahimik's unquestioned position on war and colonial history and how he envisions the relationship of Filipinos with both these former colonizers. The image of the bell, of course, brings to mind the Balangiga Bells, which American forces brought to F. E. Warren Air Force Base in Cheyenne, Wyoming as war booty after the so-called Balangiga "massacre" in 28 September 1901. Around the time when Kidlat's film was produced, the Philippine government was urging the American government to return the bells to the island of Samar, so that it could peal again in time for the centennial celebrations of the Philippine Declaration of Independence on 12 June 1998. The act of returning the bells could signal a kind of reconciliation, if not a total revision of the meaning of that other and earlier atrocious PhilippineAmerican War, which broke out after the Filipinos declared their independence from Spain. But unlike Kidlat's unprovoked mission to send a bomb back as a bell, the return of the Balangiga Bells to the Philippines has yet to happen. The gesture of Kidlat is also significant, because Igorots valiantly fought the Japanese side-by-side with Americans during World War II. For a discussion on the significance of the Balangiga "massacre" of 1901 for both Filipinos and Americans, see Delmendo, The Star-Entangled Banner 168-198; and Couttie.For a short account of Igorots and Americans fighting against the Japanese, see Scott, Of Igorots and Independence 6o-65.

5. Lit., Two Offerings, One Souvenir.

6. De Guia characterizes Kidlat Tahimik's filmmaking practice as emanating from a Bathala na attitude. Drawing upon the work of anthropologist, Alfredo Lagmay, she argues that this attitude is the cultural response of a people who live along the Pacific Ring of Fire, constantly struggling against volcanoes and storms and creatively dealing with nature. As such, a culture of resistance is supposedly embedded in indigenous knowledge, from which Kidlat draws inspiration. See "Bathala Na!" 81-121; see also Lagmay, "Bahala Na." Kidlat, himself, differentiates between Bathala na and bahala na. The former is the act of resigning to "Cosmic Will," after one has given the "best energies, best inputs, best heart into any endeavor." The latter is a "bastardization" of Bathala $n a$, which comes from "the feeling of helplessness working for colonial masters," institutionalized by our colonial education system ("Midlife Choices" 41).

7. Christopher Pavsek qualifies this label and describes Kidlat as arriere-garde. Pavsek argues, following Alexander Kluge, that "the proper stance for an aesthetic and political avant-garde is to be behind the times: [...] the aim of the arriere-garde is not to 'establish the new' but instead to 'bring everything forward' 
from the past. This stems from Pavsek's argument regarding the "utopia of film," a qualitatively political dimension of cinema that he ascribes to the films of Kidlat. Pavsek asserts that "the history of cinema must be understood not as the history of its grand achievements, but rather as the history of unrealized possibilities, thwarted ambitions, and disappointed hopes; the 'promises that are contained in the history of film' [quoting Kluge] have not been met and are too little known, but they persist, especially for those sensitive to their call, awaiting their realization." See The Utopia of Film (ch. 2).

8. Personal Interview, May 2009.

9. These essays are gathered together in the anthology by Michael T. Martin, New Latin American Cinema.

10. Although the meaning and politics of Third Cinema have been reconfigured beyond its original conception in Latin American cinemas, cf. Gabriel; Guneratne and Dissanayake.

11. The term "Igorot" is the collective name of the ethnic groups that inhabit the mountains of Northern Luzon. These highland peoples dwell in the provinces of the Cordillera Administrative Region (CAR), namely Abra, Apayao, Benguet, Kalinga, Ifugao, and Mountain Province. "Igorot," an indigenous word which literally means "mountain people," has taken on layers of connotation, both positive and negative, through the years of Spanish and American colonial rule. While no records show that the peoples in question have called themselves Igorot early on, records do indicate that Spaniards have referred to the highlanders of this region as Igorots (variously spelled) from the time of their first contact, and that the Americans have adopted the same name to refer to these peoples. "Igorot" has also been the name used to describe these peoples in the 1887 and 1904 expositions that Guieb mentions. "Ifugao" roughly means "mountain people" as well, sometimes used interchangeably with "Igorot" even by Cordillerans, but "Ifugao" specifically refers to the inhabitants of Ifugao province. Kidlat is, then, an Igorot, having been raised in Baguio City, Benguet, and an Ifugao, for his life-defining decision to move to Hapao, Ifugao, from the city. For a discussion on the origins and shifting uses of the name "Igorot," upon which this note is based, see Scott, Of Igorots and Independence, 41-70.

12. An allusion to and play on Vilgot Sjöman's I Am Curious-Yellow (1967), an offbeat Swedish film about an angry young woman whose search for political commitment drives her around to asking people about the labor movement, socialism, nonviolence, and other related ideas. 
13. There is, however, a limitation in asserting the subject-position of Kidlat Tahimik as coming "from below" or as a representative of the "folk." As Rolando B. Tolentino argues, Kidlat typifies "the problematics of the Filipino middle-class" (“Subjectivity," 116).

14. The notion of "cultural loss," a key idea in the cultural politics of indigenous peoples, sheds light on the self-conscious balancing act of Kidlat as insider and outsider of Ifugao culture. For related discussion, see Mendoza; and Kirsch.

15. Personal interview, May 2009.

16. There are popular beliefs, not uncontested, that the "moonbuggy" and the "yoyo" were invented by Filipinos. Kidlat does not assert whether or not these beliefs are founded, but, instead, builds on these "rumors" for his own brand of "Third World" humor.

17. Though even this position, if Kidlat had taken it in his early films, is a marked development from the racist nationalism that the Europe-educated ilustrados had expressed, by condescending toward and distancing themselves from the Igorots, when they beheld the Igorotes Exposicion in 1887. See Aguilar.

18. See, for example, Desiree Caluza, "Kidlat is Urian Awardee" and Perry Gil S. Mallari, "Godfather of Independent Filmmaking in the Philippines.

19. Personal interview, May 2009. 


\section{Works Cited}

Ahmad, Aijaz. "Jameson's Rhetoric of Otherness and the 'National Allegory." Social Text 17(Autumn, 1987): 3-25. Print.

Aguilar, Filomeno V., Jr. “Tracing Origins: 'Ilustrado' Nationalism and the Racial Science of Migration Waves. The Journal of Asian Studies 64:3 (Aug., 2005): 605-637. Print.

Aufderheide, Patricia. "Perfumed Nightmare." Cross-Cultural Film Guide, n.p., 1992. Web. 12 June 2009.

Bernal, Ishmael, dir. Nunal sa Tubig [A Speck in the Lake]. Script. Jorge Arago. Perf. Elizabeth Oropesa, Daria Ramirez, and George Estregan. Crown Seven Film Productions, 1976. Film

Brocka, Lino, dir. Bayan Ko: Kapit sa Patalim [My Country: Gripping the Knife's Edge]. Script. Jose F. Lacaba. Perf. Philip Salvador, and Gina Alajar. Malayan Films, Stephan Films, 1985. Film.

---, dir. Insiang. Script. Mario O’Hara. Perf. Hilda Koronel, Ruel Vernal, Mona Lisa, and Rez Cortez. Cinemanila Corporation, 1976. Film.

--, dir. Miguelito: Ang Batang Rebelde [Miguelito: The Young Rebel]. Script. Jose Dalisay, Jr. Perf. Aga Muhlach, Nida Blanca, Gloria Romero, and Eddie Garcia. D' Wonder Films, Inc., 1984. Film.

---, dir. Orapronobis [Pray for $U s]$ ].Script. Jose F. Lacaba. Perf. Philip Salvador, Bembol Roco, Gina Alajar, and Dina Bonnevie. Cannon Films, 1989. Film.

---, dir. and story. Tinimbang Ka Ngunit Kulang [You Were Weighed and Found Wanting]. Script. Mario O'Hara. Perf. Lolita Rodriguez, Mario O'Hara, Christopher de Leon, Hilda Koronel, and Eddie Garcia. Cinemanila Corporation, 1974. Film.

Caluza, Desiree. "Kidlat is Urian Awardee." Inquirer.Net. Philippine Daily Inquirer, 29 Sept. 2008. Web. 12 June 2009.

Canilao, Michael Armand P. Of Gold, Spanish Conquistadors, E Ibaloi Generational Memory. Baguio City: University of the Philippines, Cordillera Studies Center, 2011. Print. 
Casumbal-Salazar, Melisa S.L. "The Indeterminacy of the Philippine Indigenous Subject: Indigeneity, Temporality, and Cultural Governance." Amerasia Journal 41:1 (2015): 74-94. Print.

Cervantes, Behn, dir. Sakada [Sugar Plantation Peon]. Script. Lualhati Bautista, Oscar Miranda. Perf. Robert Arevalo, Hilda Koronel, Pancho Magalona, and Bembol Roco. Sagisag Films, 1976. Film.

Chaterjee, Partha. The Nation and Its Fragments: Colonial and Postcolonial Histories. Princeton: Princeton UP, 1993. Print.

Concio, Lupita A., dir. Minsa'y Isang Gamu-Gamo [Once a Moth]. Script. Marina FeleoGonzales. Perf. Nora Aunor, Jay Ilagan, Gloria Sevilla, and Perla Bautista. Premiere Productions, Inc. 1976. Film.

Couttie, Bob. Hang the Dogs: The True Tragic History of the Balangiga Massacre. Quezon City: New Day Publishers, 2004. Print.

Crofts, Stephen. "Authorship and Hollywood." The Oxford Guide to Film Studies. Eds. John Hill and Pamela Church Gibson. Oxford: Oxford UP, 1998. 310-24. Print.

David, Joel. Wages of Cinema: Film in Philippine Perspective. Quezon City: $\mathrm{U}$ of the Philippines P, 1998. Print.

David, Randolf. Silence. Photography by Jaime Zobel.Makati: Heritage Library, 2002. Print.

De Guia, Katrin. "Bathala Na! In the Spirit of the Ancestors. Kidlat Tahimik: The Cosmic Warrior." Kapwa: The Self in the Other. Pasig City: Anvil Publishing Inc., 2005. 81-121.Print.

De Leon, Mike, dir. Itim [Rites of May].Script. Clodualdo del Mundo, Jr. and Gil Quito. Perf. Charo Santos, Tommy Abuel, and Mario Montenegro. Cinema Artists Philippines, 1976. Film.

Delmendo, Sharon. The Star-Entangled Banner: One Hundred Years of America in the Philippines. Quezon City: U of the Philippines P, 2005. Print.

Espinosa, Julio García. "For an Imperfect Cinema." New Latin American Cinema, Vol. 1: Theory, Practice and Transcontinental Articulations. Ed.Michael T. Martin. Detroit: Wayne State U P, 1997. 71-82. Print.

Foucault, Michel. "What Is an Author?" The Foucault Reader. Ed. Paul Rabinow. New York: Pantheon Books, 1984.101-120. Print. 
Gabriel, Teshome. "Third Cinema as Guardian of Popular Memory: Towards a Third Aesthetics." Questions of Third Cinema. Eds. Jim Pines and Paul Willemen. London: British Film Institute, 1989. 53-64. Print.

Guieb, Eulalio R. III. "Worlding the Third World (O Kung Paanong Nagkakadaigdig ang Ikatlong Daigdig sa Mga Pelikula ni Kidlat Tahimik)." Communication and Media Theories. Eds. Rolando B. Tolentino, Patrick F. Campos, Choy S. Pangilinan, and Randy Jay C. Solis. Quezon City: U of the Philippines P, 2014. 473-479. Print.

Guneratne, Anthony R. and Wimal Dissanayake, eds. Rethinking Third Cinema. New York: Routledge, 2003. Print.

Hardt, Michael and Antonio Negri. Empire. Cambridge: Harvard UP, 20oo. Print.

Herzog, Werner, dir. and scriptwriter.The Enigma of Kasper Hauser. Perf. Bruno Schleinstein, Brigitte Mira, Walter Ladengast, and Willy Semmelrogge. Werner Herzog Filmproduktion, and Filmverlag der Autoren ZDF, 1974. Film.

Hillier, Jim, ed. Cahiers du Cinema. Volume 1: The 1950s, Neorealism, Hollywood, the New Wave. London: RKP/BFI, 1985. Print.

Jameson, Fredric. "Art Naï' and the Admixture of Worlds." The Geopolitical Aesthetic: Cinema and Space in the World System. Bloomington: Indiana UP, 1992. 186-213. Print.

Kidlat Tahimik, dir. and scriptwriter. Bahag Ko, Mahal Ko [Japanese Summers of a Filipino Fundoshi]. Cinematrix, and Kidlat Tahimik. 1996. Film.

--, dir. Bakit Dilaw ang Gitna ng Bahaghari? [Why is Yellow the Middle of the Rainbow?]. Script. Kidlat Tahimik, Kidlat Gottlieb Kalayaan, Kawayan Thor Kalayaan, and Kabunian Cedric Enrique. Third World Projector, and Sunflower Film and Video Cooperative. 1994. Film.

--, dir. and scriptwriter. Bubong! [Roofs of the World! UNITE!]. Kidlat Tahimik, 2006. Film.

---. "Cups-of-Gas Filmmaking vs. Full-Tank-cum-Credit Card Fillmaking." Discourse 11. 2 (Spring-Summer 1989): 81-86. Print.

--, dir. and scriptwriter. Dalawang Atang at Isang Pasalubong [Our Film-Grimage to Guimaras]. Kidlat Tahimik, 2006.Film. 
---, dir. and scriptwriter. Mababangong Bangungot [Perfumed Nightmare]. Perf. Kidlat Tahimik, Mang Fely, Dolores Santamaria, and Hartmut Lerch. Kidlat Tahimik, 1977. Film.

--. "Midlife Choices: Filmmaking vs. Fillmaking." Primed for Life: Writings on Midlife by 18 Men. Ed. Lorna Kalaw-Tirol. Pasig City: Anvil Publishing, 1997. 11-59. Print.

--, dir. and scriptwriter. Our Bomb Mission to Hiroshima. Kidlat Tahimik, 1995. Film.

--.. Personal Interview. May 2009.

--, dir. and scriptwriter. Sino ang Lumikha ng Yoyo? Sino ang Lumikha ng Moon Buggy? [Who Invented the Yoyo? Who Invented the Moon Buggy?]. Kidlat Tahimik, 1981. Film.

--, dir. and scriptwriter. Some More Rice. Kidlat Tahimik. 2005. Film.

---, dir. and scriptwriter. Takedera Mon Amour. Japan Foundation, Hoso Bunka Foundation, Sunflower Film and Video Collective, 1989. Film.

---, dir. and scriptwriter.Turumba. Perf. Homer Abiad, Iñigo Vito, Maria Pehipo, Patricio Abari. Kidlat Kulog Productions, 1983. Film.

--. “UP Gawad Plaridel (2009): A Multimedia Lecture." Plaridel 8.2 (Aug. 2011): 117-146. Print.

Kirsch, Stuart. "Lost Worlds: Environmental Disaster, 'Culture Loss', and the Law." Current Anthropology 42.2 (2001): 167-198. Print.

Kurosawa, Akira, dir. Seven Samurai. Scriptwriter Shinobu Hashimoto, and Hideo Oguni. Perf. Toshirô Mifune, Takashi Shimura, Keiko Tsushima, and Kamatari Fujiwara. Toho Company, 1954. Film.

Lagmay, Alfredo. "Bahala Na." Ulat ng Ikalawang Pambansang Kumperensiya sa Sikolohiyang Pilipino. Eds. Lilia F. Antonio, Lavial Samson, Esther Reyes, and Elena Paguio. Quezon City: Pambansang Samahan sa Sikolohiyang Pilipino, 1977. 120-130. Print.

Lim, Felicidad C. "Perfumed Nightmare and the Perils of Jameson's 'New Political Culture." Philippine Critical Forum 1.1 (1995): 24-37. Print.

Mallari, Perry Gil S. "Godfather of Independent Filmmaking in the Philippines." Manila Times, 10 Aug. 2008. Web. 12 June 2009. 
Martin, Michael T. New Latin American Cinema, Vol. 1: Theory, Practice and Transcontinental Articulations. Detroit: Wayne State UP, 1997. Print.

Maule, Rosanna. Beyond Auteurism: New Directions in Authorial Film Practices in France, Italy, and Spain Since the 1980s. Bristol: Intellect, 2008. Print.

Mendoza, Julius D. "Alterity and Cultural Existence." Cordillera in June: Essays Celebrating June Prill-Brett, Anthropologist. Ed. B.P. Tapang. Quezon City: U of the Philippines P, 2007. 1-29. Print.

O'Hara, Mario, dir. and scriptwriter. Tatlong Taong Walang Diyos [Three Godless Years]. Script. Jose F. Lacaba. Perf. Nora Aunor, Christopher de Leon, and Bembol Roco. NV Productions, 1976. Film.

Palangchao, Harley. “Japanese Soldiers' Bones Burned in Banaue Village." Baguio Midland Courier. n.p., 29 Nov. 2009. Web. 1 Dec. 2009.

Pavsek, Christopher. The Utopia of Film: Cinema and Its Futures in Godard, Kluge, and Tahimik. New York: Columbia UP, 2013. epub file.

Rocha, Glauber. "An Esthetic of Hunger." New Latin American Cinema, Vol. 1: Theory, Practice and Transcontinental Articulations. Ed.Michael T. Martin. Detroit: Wayne State UP, 1997. 59-61. Print.

Romero, Eddie, dir. and scriptwriter. Ganito Kami Noon, Paano Kayo Ngayon? [This Was How We Were, What Happens to You Now?]. Screenplay by Roy Iglesias. Perf. Christopher de Leon, Gloria Diaz, and Eddie Garcia. Hemisphere Pictures Inc., 1976. Film.

San Juan, E. Jr. "Cinema of the 'Naïve'Subaltern in Search of an Audience." Geopolitics of the Visible: Essays on Philippine Film Cultures. Ed. Rolando B. Tolentino. Quezon City: Ateneo de Manila UP, 20oo. 264-276. Print.

--. "On the Cinematic Art of Kidlat Tahimik.” The Philippines Matrix Project. n.p., 6 Aug. 2008. Web. 12 June 2009.

Sanjinés, Jorge. "Problems of Form and Content in Revolutionary Cinema." New Latin American Cinema, Vol. 1: Theory, Practice and Transcontinental Articulations. Ed.Michael T. Martin. Detroit: Wayne State UP, 1997. 62-70. Print. 
Scott, William Henry. "Igorot Responses to Spanish Aims: 1576-1896." History on the Cordillera: Collected Writings on Mountain Province History. Baguio City: Baguio Printing \& Publishing Co., Inc., 1975. 182-201. Print.

--. Of Igorots and Independence. Baguio City: ERA, 1993. Print.

Shohat, Ella and Robert Stam. Unthinking Eurocentrism: Multiculturalism and the Media. London: Routledge, 1994. Print.

Sjöman, Vilgot, dir. and scriptwriter. I Am Curious-Yellow. Perf. Vilgot Sjöman, Anders Ek, Holger Löwenadler, Martin Luther King, Olof Palme, and Yevgeni Yevtushenko. Janus Films, 1967. Film.

Solanas, Fernando and Octavio Getino. "Towards a Third Cinema." New Latin American Cinema, Vol. 1: Theory, Practice and Transcontinental Articulations. Ed.Michael T. Martin. Detroit: Wayne State UP, 1997. 33-58. Print.

Staiger, Janet and David A. Gerstner, eds. Authorship and Film. New York: Routledge, 2003. Print.

Stam, Robert. "Beyond Third Cinema: The Aesthetics of Hybridity." Rethinking Third Cinema. Eds. Anthony R. Guneratne and Wimal Dissanayake. New York: Routledge, 2003. 29-48. Print.

Tolentino, Delfin, Jr., ed. Resistance and Revolution in the Cordillera. Baguio City: University of the Philippines College Baguio, 1994. Print.

Tolentino, Rolando B. “Jameson and Kidlat Tahimik." Philippine Studies 44 (First Quarter 1996): 113-125. Print.

--. "Kidlat Tahimik: Tagahawan ng Landas ng Philippine Independent Cinema." Manunuri ng Pelikulang Pilipino.Com. n.p., 2008. Web. 1July 2009.

--. "Subjectivity and Nation in Filipino Autobiographical Documentaries." National/ Transnational: Subject Formation and Media in and on the Philippines. Quezon City: Ateneo de Manila UP, 2001. 112-124. Print.

Yuson, Alfred, dir. Shaman Wars. Alfred Yuson, 1996.Film.

Zulueta, Lito. "Kidlat Tahimik goes 'Imeldific.' Inquirer.net. Philippine Daily Inquirer, 4 May 2009. Web. 12 June 2009. 